\title{
What do academicians know about periodic health examinations?
}

\author{
EMRAH ERSOYA, B, D-F , ESRA SAATCIA, D-F
}

Cukurova University School of Medicine, Department of Family Medicine, Adana, Turkey

A - Study Design, B - Data Collection, C - Statistical Analysis, D - Data Interpretation, E - Manuscript Preparation, F - Literature Search, G - Funds Collection

Summary Background. A periodic health examination is a regular health check program for healthy people who have not yet demonstrated a disease.

Objectives. Evaluation of the level of knowledge, perception and status of action for periodic health examinations of academicians at Cukurova University.

Material and methods. Our sample was 392 academicians at Cukurova University. The participants completed a socio-demographic questionnaire ( 9 items), a questionnaire for knowledge on periodic health examinations (19 items), a questionnaire for perception of periodic health examinations ( 27 items) and a questionnaire about visits to have a periodic health examinations ( 24 items). The data was analyzed using the SPSS statistical analysis program.

Results. Of the participants, $143(69.8 \%)$ were from the Faculty of Medicine, and 62 (30.2\%) were from the Faculty of Agriculture (205 participants). The average age was $49.5 \pm 9.2$ years. Of the participants, $56.4 \%$ (116) were male, $26.9 \%(54)$ were smokers, $74.2 \%(152)$ were consuming alcoholic drinks, $25.3 \%$ (52) were doing regular exercise, $38.7 \%$ (24) were eating/drinking healthily. Participants who evaluated their overall health status as 'moderate' were more willing to undergo screening tests, $76 \%(156)$ said that they had measured their body mass index, $82.4 \%$ (169) had their blood lipid levels checked, and $94.1 \%$ (193) had their blood pressure measured. As the age of participants increased, the frequency of blood pressure measurement increased. Of the female participants, $52.3 \%(46)$ has had a Pap smear, and $48.9 \%$ (43) had undergone a mammography.

Conclusions. The low rate of periodic health examinations suggests that family physicians have more to do to increase the awareness levels of even highly educated individuals about the benefits of periodic health examinations.

Key words: academicians, Cukurova University, Turkey, family medicine, periodic health examination.

Ersoy E, Saatci E. What do academicians know about periodic health examinations? Fam Med Prim Care Rev 2017; 19(4): 361-365, doi: https://doi.org/10.5114/fmpcr.2017.70808.

\section{Background}

Preventive services, being the basis of primary health care, contain to avoid from risks behaviors for healthy individuals, to reduce the risks of individuals at risk, to give an opportunity for early diagnosis and treatment of existing diseases and to prevent from permanent damages of chronic diseases. These basic targets are achieved through periodic health examinations (PHE), which are set by the recommendations of various national and international guidelines [1]. PHE is a specific, effective, feasible and acceptable follow-up program tailored to healthy people [2-4].

The Ministry of Health in Turkey updated the PHE and Screening Tests Guideline for family physicians in 2015. Many screening tests, including the Pap smear and fecal occult blood test, could be performed easily in family practice clinics.

In Turkey, about 100 thousand people die due to diseases caused by tobacco every year [5]. In a study in 2012, the smoking rate was found at $27 \%$ for individuals 15 years of age and older, whereas it was $31.3 \%$ in 2008 in Turkey [6].

The Burden of Disease Study in Turkey showed that $4.3 \%$ of diseases could be prevented through regular physical activity [7]. The National Household Survey showed that $36 \%$ of the Turkish population did not perform regular physical activity [8].

The World Health Organization Alcohol Report 2014 declared that alcohol consumption was the main cause of deaths due to liver cirrhosis and traffic accidents in Turkey [9].

The rate of alcohol consumption was $17.2 \%$ for males and $3.8 \%$ for females, a total of $10.4 \%$ according to 2012 data in Turkey [10].
Only $34.4 \%$ of 15 -year and older individuals had their cholesterol levels measured according to 2014 data in Turkey [11].

In 2015, 15,352 deaths occurred in Turkey due to hypertensive diseases [12].

The most common cancer in females is breast cancer, causing 3959 deaths in Turkey in 2015 [12].

According to 2012 Turkish Health Statistics data, only one in five women have been screened for breast cancer via mammography [10].

The PHE and Screening Tests Guideline for Family Practice in Turkey recommend screening for depression with two simple questions [13].

\section{Objectives}

Our aim in this study was to determine the level of knowledge, perception and status of action for periodic health examinations of academicians at Cukurova University and related socio-demographic factors and health-related behaviors.

\section{Material and methods}

\section{Research design and setting}

Our sample was the academic staff (assistant professors, associate professors and professors) of the Faculty of Medicine 
(275) and Faculty of Agriculture (117) at Cukurova University. All participants gave informed verbal consent. Participants completed a socio-demographic questionnaire (9 items), a questionnaire for knowledge (19 items), perception ( 27 items) and about visits to have a periodic health examinations (24 items). The questionnaires were completed via the face-to-face interview method between 1 October 2015 to 28 February 2016.

\section{Data Analysis} gram.

Data was analyzed using the SPSS 21 statistical analysis pro-

Demographic data was analyzed as numbers and percentages. Cross tables were used and analyzed using $x^{2}$ and ANOVA tests. The level of significance was set as $p<0.05$.

We used the Shapiro-Wilk test to check distribution of variables. There were variables with normal distribution such as age, smoking, exercise, starting age and frequency for BMI measurement and frequency for blood lipid profile measurement. There were also variables without normal distribution such as socio-economic status, marital status, alcohol consumption, blood lipid profile measurement and positive family history for cancer.

\section{Ethical approval}

The study was approved by the Ethics Committee of the Faculty of Medicine of Cukurova University.

\section{Results}

The response rate for the Faculty of Medicine was $81 \%$ (223), and the number of valid questionnaires was 143 (64\%). The response rate for the Faculty of Agriculture was $79 \%$ (93), and the number of valid questionnaires was $62(66 \%)$. The overall response rate was $80.6 \%$ (316), and the number of valid questionnaires was 205 (65\%).

The average age was $49.5 \pm 9.2$ years. Of the participants, $56.6 \%$ (116) were male, and $81.4 \%$ (167) were married. $63.9 \%$ (131) stated their socio-economic status was (medium-high) (Table 1). Of the participants, $26.9 \%$ (54) were smokers. The rate of alcohol consumption was $74.2 \%$ (152). Of the participants, $25.3 \%$ (52) were doing regular exercise more than 150 minutes per week, with only $39.1 \%(80)$ having healthy nutritional habits (Table 1).

Of the participants, $94.1 \%(193)$ had their blood pressure measured within the last two years, $82.4 \%(169)$ had their blood lipid profile measured during the last five years, $76 \%$ (156) had their body mass index (BMI) measured in the last year, and $14.6 \%(30)$ were screened for depression at least once.

\begin{tabular}{|c|c|c|c|c|}
\hline Characterist & & $\begin{array}{l}\text { Faculty of } \\
\text { Medicine } \\
n(\%)\end{array}$ & $\begin{array}{l}\text { Faculty of } \\
\text { Agriculture } \\
n(\%)\end{array}$ & $\begin{array}{l}\text { Total } \\
n(\%)\end{array}$ \\
\hline \multicolumn{2}{|c|}{ Number of participants } & $143(69.8)$ & $62(30.2)$ & $205(100)$ \\
\hline \multicolumn{2}{|c|}{ Mean age (SD) } & $48.25(9.1)$ & $52.4(8.9)$ & $49.5(9.2)$ \\
\hline \multicolumn{2}{|l|}{ Male } & 77 (53.9) & 39 (62.9) & $116(56.6)$ \\
\hline \multicolumn{2}{|l|}{ Female } & $66(46.1)$ & $23(37.1)$ & 89 (43.4) \\
\hline \multicolumn{2}{|c|}{ Married/living together } & $114(79.7)$ & $53(85.5)$ & $167(81.4)$ \\
\hline \multirow{2}{*}{\begin{tabular}{|l} 
Socio-eco- \\
nomic \\
status
\end{tabular}} & $\begin{array}{l}\text { medium- } \\
\text {-high }\end{array}$ & $89(62.2)$ & $42(67.7)$ & 131 (63.9) \\
\hline & moderate & $29(20.3)$ & $16(25.8)$ & 45 (21.9) \\
\hline \multirow{2}{*}{$\begin{array}{l}\text { Household } \\
\text { income } \\
\text { per month } \\
\text { (euros) }\end{array}$} & $\begin{array}{l}1300- \\
-1900\end{array}$ & $29(20.3)$ & $29(46.8)$ & $58(28.2)$ \\
\hline & $>1900$ & $102(71.3)$ & $23(37.1)$ & 125 (60.9) \\
\hline
\end{tabular}

\begin{tabular}{|c|c|c|c|c|}
\hline \multirow{3}{*}{$\begin{array}{l}\text { Smoking } \\
\text { (cigarettes) }\end{array}$} & $<10$ & $21(14.6)$ & $7(11.3)$ & $28(13.6)$ \\
\hline & $10-19$ & $11(7.7)$ & $5(8.1)$ & $16(7.8)$ \\
\hline & $\geq 20$ & $8(5.6)$ & $2(3.2)$ & $10(4.7)$ \\
\hline \multirow{2}{*}{$\begin{array}{l}\text { Alcohol } \\
\text { consump- } \\
\text { tion }\end{array}$} & rarely* & $79(55.2)$ & $48(77.4)$ & 127 (61.9) \\
\hline & $\begin{array}{l}\text { twice } \\
\text { a week } \\
\text { and more }\end{array}$ & $23(16.1)$ & $2(3.2)$ & $25(12.1)$ \\
\hline \multicolumn{2}{|c|}{ Regular exercise** } & $40(27.9)$ & $12(19.4)$ & $52(25.3)$ \\
\hline \multicolumn{2}{|l|}{ Healthy diet } & $55(38.5)$ & $23(37.1)$ & $78(38.0)$ \\
\hline
\end{tabular}

*Once a month; ${ }^{* *}$ more than 150 minutes per week.

Of the female participants, $52.3 \%$ (46) had a Pap smear test in the last five years, and $48.9 \%$ (43) had a mammography in the last two years.

Of the 50-year and older respondents, $19.4 \%$ (20) had a colonoscopy in the last ten years, and $16.5 \%$ (17) had a fecal occult blood test in the last year.

Of the participants, only $38.5 \%$ (79) have been immunized against tetanus in the last ten years, and only $28.7 \%$ (59) had an influenza vaccination in the last year (Table 2).

The most preferred health care institution for screening tests was the university hospital $(62.4 \%, 128)$. A familiar physician (such as a friend) was the second most preferred $(14.6 \%$, 30). Only $4.3 \%$ (9) of the participants had their screening tests performed by their family physician.

\begin{tabular}{|l|l|l|l|}
\hline \multicolumn{4}{|l|}{ Table 2. Screening and vaccination status of participants } \\
\hline Characteristics $(n)$ & $\begin{array}{l}\text { Faculty of } \\
\text { Medicine } \\
n(\%)\end{array}$ & $\begin{array}{l}\text { Faculty of } \\
\text { Agriculture } \\
n(\%)\end{array}$ & $\begin{array}{l}\text { Total } \\
n(\%)\end{array}$ \\
\hline Body mass index (205) & $116(81.1)$ & $40(64.5)$ & $156(76.0)$ \\
\hline Blood lipid profile (205) & $121(84.6)$ & $48(77.4)$ & $169(82.4)$ \\
\hline Blood pressure (205) & $133(93.0)$ & $60(96.8)$ & $193(94.1)$ \\
\hline Depression (205) & $23(16.1)$ & $7(11.3)$ & $30(14.6)$ \\
\hline Mammography (88)* & $35(53.0)$ & $8(34.8)$ & $43(48.9)$ \\
\hline Pap smear test (88)* & $35(53.0)$ & $11(47.8)$ & $46(52.3)$ \\
\hline $\begin{array}{l}\text { Fecal occult blood test } \\
(103)^{* *}\end{array}$ & $14(22.2)$ & $6(15.0)$ & $20(19.4)$ \\
\hline Colonoscopy (103)** & $11(17.4)$ & $6(15.0)$ & $17(16.5)$ \\
\hline Influenza (205) & $40(27.9)$ & $19(30.7)$ & $59(28.7)$ \\
\hline Hepatitis B (205) & $97(67.8)$ & $20(32.3)$ & $117(57.1)$ \\
\hline Tetanus (205) & $62(43.4)$ & $17(27.4)$ & $79(38.5)$ \\
\hline
\end{tabular}

*Female participants; **50-year and older participants.

\section{Opinions about screening tests}

Of the participants, 59.5\% (122) were in favor of undergoing screening tests (Table 3 ).

\begin{tabular}{|l|l|l|l|}
\hline \multicolumn{4}{|c|}{ Table 3. Opinions of participants for screening tests } \\
\hline Opinions & $\begin{array}{l}\text { Faculty of } \\
\text { Medicine } \\
n(\%)\end{array}$ & $\begin{array}{l}\text { Faculty of } \\
\text { Agriculture } \\
n(\%)\end{array}$ & $\begin{array}{l}\text { Total } \\
n(\%)\end{array}$ \\
\hline $\begin{array}{l}\text { I am in favor of screen- } \\
\text { ing tests }\end{array}$ & $88(61.5)$ & $34(54.8)$ & $122(59.5)$ \\
\hline $\begin{array}{l}\text { I am not in favor of } \\
\text { screening tests }\end{array}$ & $15(10.5)$ & $10(16.1)$ & $25(12.1)$ \\
\hline $\begin{array}{l}\text { I do not undergo screen- } \\
\text { ing tests, because I do } \\
\text { not have enough time }\end{array}$ & $18(12.6)$ & $2(3.2)$ & $20(9.7)$ \\
\hline $\begin{array}{l}\text { I was not having regular } \\
\text { screening tests, but my } \\
\text { opinion has changed }\end{array}$ & $7(4.9)$ & $3(4.8)$ & $10(4.8)$ \\
\hline
\end{tabular}




\begin{tabular}{|l|l|l|l|}
\hline \multicolumn{4}{|l|}{ Table 3. Opinions of participants for screening tests } \\
\hline Opinions & $\begin{array}{l}\text { Faculty of } \\
\text { Medicine } \\
n(\%)\end{array}$ & $\begin{array}{l}\text { Faculty of } \\
\text { Agriculture } \\
n(\%)\end{array}$ & $\begin{array}{l}\text { Total } \\
n(\%)\end{array}$ \\
\hline $\begin{array}{l}\text { I do not undergo } \\
\text { screening tests, because } \\
\text { I forget }\end{array}$ & $4(2.8)$ & $7(11.3)$ & $11(5.3)$ \\
\hline $\begin{array}{l}\text { I do not undergo screen- } \\
\text { ing tests, because I am } \\
\text { healthy }\end{array}$ & $4(2.8)$ & $2(3.2)$ & $6(2.9)$ \\
\hline $\begin{array}{l}\text { I do not undergo } \\
\text { screening tests, because } \\
\text { I am not at the age for } \\
\text { screening }\end{array}$ & $2(1.4)$ & $1(1.6)$ & $3(1.5)$ \\
\hline $\begin{array}{l}\text { Screening tests are time } \\
\text { consuming and difficult }\end{array}$ & $0(0.0)$ & $2(3.2)$ & $2(0.9)$ \\
\hline
\end{tabular}

\section{Knowledge about screening tests}

Of the participants, $44.3 \%$ (91) thought that BMI measurements for healthy adults should be started at 18-29 years of age and $35.6 \%$ (73) stated that these should be measured once a year (Table 4).

Of the participants, $40.5 \%$ (83) stated that blood pressure measurements should be started at 18-29 years of age, and $25.4 \%$ (52) stated that blood pressure should be measured once a year (Table 4).

Of the participants, $12.7 \%$ (26) thought that blood lipid profile should be measured every five years, and $20.5 \%$ (42) stated that blood lipid measurements should be started at 35-39 years of age (Table 4).

Of the participants, $23.4 \%$ (48) thought that a Pap smear test should be performed every three years, and $28.3 \%$ (58) stated that a Pap smear test should be started at 18-29 years of age (Table 4).

\begin{tabular}{|c|c|c|c|c|}
\hline \multicolumn{2}{|c|}{ Screening tests } & $\begin{array}{l}\text { Faculty of } \\
\text { Medicine* } \\
\text { (\%) }\end{array}$ & $\begin{array}{l}\text { Faculty of } \\
\text { Agriculture* } \\
\text { (\%) }\end{array}$ & $\begin{array}{l}\text { Total* } \\
(\%)\end{array}$ \\
\hline \multirow[t]{2}{*}{$\begin{array}{l}\text { Body } \\
\text { mass } \\
\text { index }\end{array}$} & frequency & $\begin{array}{l}\text { once } \\
\text { a month } \\
(32.2)\end{array}$ & $\begin{array}{l}\text { once a year } \\
(45.2)\end{array}$ & $\begin{array}{l}\text { once a year } \\
(35.6)\end{array}$ \\
\hline & $\begin{array}{l}\text { starting } \\
\text { age }\end{array}$ & $\begin{array}{l}18-29 \\
(44.8)\end{array}$ & $\begin{array}{l}18-29 \\
(43.6)\end{array}$ & $\begin{array}{l}18-29 \\
(44.3)\end{array}$ \\
\hline \multirow[t]{2}{*}{$\begin{array}{l}\text { Blood } \\
\text { pressure }\end{array}$} & frequency & $\begin{array}{l}\text { once } \\
\text { a month } \\
(37.1)\end{array}$ & $\begin{array}{l}\text { once } \\
\text { a month } \\
(37.1)\end{array}$ & $\begin{array}{l}\text { once } \\
\text { a month } \\
\text { (37.1) }\end{array}$ \\
\hline & $\begin{array}{l}\text { starting } \\
\text { age }\end{array}$ & $\begin{array}{l}18-29 \\
(41.9)\end{array}$ & $\begin{array}{l}18-29 \\
(37.1)\end{array}$ & $\begin{array}{l}18-29 \\
(40.5)\end{array}$ \\
\hline \multirow[t]{2}{*}{$\begin{array}{l}\text { Blood lipid } \\
\text { profile }\end{array}$} & frequency & $\begin{array}{l}\text { once a year } \\
(46.8)\end{array}$ & $\begin{array}{l}\text { once a year } \\
(61.3)\end{array}$ & $\begin{array}{l}\text { once a year } \\
(51.2)\end{array}$ \\
\hline & $\begin{array}{l}\text { starting } \\
\text { age }\end{array}$ & $\begin{array}{l}35-39 \\
45-49 \\
(20.9)\end{array}$ & $\begin{array}{l}40-44 \\
(25.8)\end{array}$ & $\begin{array}{l}35-39 \\
(20.5)\end{array}$ \\
\hline \multirow[t]{2}{*}{$\begin{array}{l}\text { Pap smear } \\
\text { test }\end{array}$} & frequency & $\begin{array}{l}\text { once a year } \\
(46.2)\end{array}$ & $\begin{array}{l}\text { once a year } \\
(45.2)\end{array}$ & $\begin{array}{l}\text { once a year } \\
(45.9)\end{array}$ \\
\hline & $\begin{array}{l}\text { starting } \\
\text { age }\end{array}$ & $\begin{array}{l}18-29 \\
(31.5)\end{array}$ & $\begin{array}{l}40-44 \\
(32.3)\end{array}$ & $\begin{array}{l}18-29 \\
(28.3)\end{array}$ \\
\hline \multirow{2}{*}{$\begin{array}{l}\text { Fecal oc- } \\
\text { cult blood } \\
\text { test }\end{array}$} & frequency & $\begin{array}{l}\text { once a year } \\
(70.6)\end{array}$ & $\begin{array}{l}\text { once a year } \\
(79.0)\end{array}$ & $\begin{array}{l}\text { once a year } \\
(73.2)\end{array}$ \\
\hline & $\begin{array}{l}\text { starting } \\
\text { age }\end{array}$ & $\begin{array}{l}50-54 \\
(44.1)\end{array}$ & $\begin{array}{l}50-54 \\
(29.0)\end{array}$ & $\begin{array}{l}50-54 \\
(39.5)\end{array}$ \\
\hline
\end{tabular}

*Top-rated responds.
Of the participants, $73.2 \%$ (150) stated that a fecal occult blood test should be performed once a year, and 39.5\% (81) thought that it should be started at 50-54 years of age (Table 4).

Of the participants, $67.8 \%$ (139) evaluated their overall health status as 'good', 18\% (37) evaluated it as 'moderate,' and $14.1 \%$ (29) evaluated it as 'very good'.

Participants in the Faculty of Agriculture who evaluated their overall health status as 'moderate' were significantly more willing to undergo screening test $(p=0.044)$. Additionally, there was a positive significant relationship between the self-assessed overall health status and exercising regularly $(p=0.018)$. However, the self-assessed overall health status was not significantly related to smoking, alcohol consumption and a healthy diet $(p>0.05)$ (Table 5).

The socio-economic status of participants in the Faculty of Medicine was significantly related to smoking behavior $(p=0.023)$ (Table 5).

Male participants were smoking more than female participants in the Faculty of Agriculture ( $p=0.045$ ) (Table 5).

As the age of participants increased, the frequency of blood pressure measurement increased in both faculties $(p=0.023$ for the Faculty Medicine and $p=0.025$ for the Faculty of Agriculture) (Table 5).

Female participants had their BMI measured more frequently than male participants $(p=0.006)$ (Table 5).

Participants of the Faculty of Medicine who had their BMI measured in the last year stated that BMI should be measured more frequently (once a month) and should be started at an earlier age (18-29 years) ( $p<0.001$ and $p<0.001$, respectively). Participants of the Faculty of Agriculture who had their BMI measured in the last year also stated that BMI measurements should be started at an earlier age (18-29 years) $(p=0.004)$ (Table 5).

Participants of the Faculty of Medicine who had their blood pressure measured recently thought that blood pressure should be measured more frequently and at an earlier age $(p<0.001$, $p<0.001$, respectively) (Table 5 ).

Participants of the Faculty of Medicine who had their blood lipid profile measured thought that blood lipid profile should be measured more frequently and should be started at an earlier age ( $p=0.020, p=0.001$, respectively) (Table 5 ).

\begin{tabular}{|c|c|c|c|}
\hline \multicolumn{2}{|c|}{ Socio-demographic factors } & $\begin{array}{l}\text { Faculty of } \\
\text { Medicine } \\
p^{*}\end{array}$ & $\begin{array}{l}\text { Faculty of } \\
\text { Agriculture } \\
p^{*}\end{array}$ \\
\hline \multirow[t]{3}{*}{ Age } & $\begin{array}{l}\mathrm{BMI}{ }^{* *} \text { measure- } \\
\text { ment }\end{array}$ & 0.621 & 0.888 \\
\hline & $\begin{array}{l}\text { blood lipid profile } \\
\text { measurement }\end{array}$ & 0.824 & 0.050 \\
\hline & $\begin{array}{l}\text { blood pressure } \\
\text { measurement }\end{array}$ & 0.023 & 0.025 \\
\hline \multirow[t]{6}{*}{ Gender } & $\begin{array}{l}\mathrm{BMI}{ }^{* *} \text { measure- } \\
\text { ment }\end{array}$ & 0.006 & 0.005 \\
\hline & \begin{tabular}{|l} 
blood lipid profile \\
measurement
\end{tabular} & 0.612 & 0.600 \\
\hline & $\begin{array}{l}\text { blood pressure } \\
\text { measurement }\end{array}$ & 0.943 & 0.903 \\
\hline & smoking & 0.911 & 0.045 \\
\hline & $\begin{array}{l}\text { alcohol consump- } \\
\text { tion }\end{array}$ & 0.113 & 0.105 \\
\hline & regular exercise & 0.975 & 0.263 \\
\hline \multirow{3}{*}{$\begin{array}{l}\text { Socio-economic } \\
\text { status }\end{array}$} & smoking & 0.023 & 0.228 \\
\hline & $\begin{array}{l}\text { alcohol consump- } \\
\text { tion }\end{array}$ & 0.622 & 0.071 \\
\hline & regular Exercise & 0.911 & 0.057 \\
\hline
\end{tabular}




\begin{tabular}{|c|c|c|c|}
\hline \multicolumn{2}{|c|}{ Socio-demographic factors } & $\begin{array}{l}\text { Faculty of } \\
\text { Medicine } \\
p^{*}\end{array}$ & $\begin{array}{l}\text { Faculty of } \\
\text { Agriculture } \\
p^{*}\end{array}$ \\
\hline $\begin{array}{l}\text { Positive fam- } \\
\text { ily history for } \\
\text { cancer }\end{array}$ & $\begin{array}{l}\text { in favor of screening } \\
\text { tests }\end{array}$ & 0.368 & 0.471 \\
\hline \multirow[t]{2}{*}{$\begin{array}{l}\mathrm{BMI} * * \text { mea- } \\
\text { surement }\end{array}$} & $\begin{array}{l}\text { frequency for } \mathrm{BMI} * * \\
\text { measurement }\end{array}$ & $<0.001$ & 0.137 \\
\hline & $\begin{array}{l}\text { starting age for } \\
\text { BMI** measure- } \\
\text { ment }\end{array}$ & $<0.001$ & 0.004 \\
\hline $\begin{array}{l}\text { Blood lipid pro- } \\
\text { file measure- } \\
\text { ment }\end{array}$ & $\begin{array}{l}\text { frequency for blood } \\
\text { lipid profile mea- } \\
\text { surement }\end{array}$ & 0.020 & 0.418 \\
\hline
\end{tabular}

*Pearson chi-square test; **Body mass index.

\section{Discussion}

Approximately 55 million people die each year in the world. Cardiovascular diseases, cancers, chronic lung diseases and accidents are the main causes of death. Factors that affect the causes of death include environmental and genetic risks, unhealthy diet, sedentary lifestyle, obesity and tobacco and alcohol consumption.

In our study, the smoking rate was $26.9 \%$, and consuming alcoholic drinks twice a week or more was $12.1 \%$. Our findings were consistent with the national rates.

BMI, blood pressure and blood lipid profile measurement rates were quite satisfactory in our sample. The higher rates of measurements in our study, compared to national rates, may be due to the high educational and social status and high awareness of diseases including hypertension, hyperlipidemia, obesity, cardiovascular diseases, etc. However, the situation was not the same for depression.

Another reason might be the ease of accessibility to care in the university hospital and the chance of having another academician in the hospital as a friend.

The lower rates of vaccinations are consistent with the national adult vaccination rates in Turkey. The PHE and Screening Tests Guideline for Family Medicine Practice in Turkey emphasized the importance of immunization in adults [13]. Immunization should be an essential part of adult health care.

In our study, female participants had better mammography rates compared to national rates. In 2015, 472 women died due to cervical cancer in Turkey [12]. More than $50 \%$ of patients with cervical cancer had never had a Pap smear test, and more than $60 \%$ of cervical cancers were diagnosed in women without screenings for cervical cancer in the past five years [14]. Only $22.1 \%$ of women were screened for cervical cancer with a Pap smear test in Turkey [10]. In our study, $52.3 \%$ of the female participants were screened for cervical cancer with a Pap smear test in the last five years. After the initiation of PHE programs in Turkey, cervical cancer screening is now easily accessible in family practice clinics.

In Turkey, 5691 deaths occurred due to malignant tumors of the colon in 2015. Colon cancer is the fourth most common cause of death through malign tumors [12]. The rate of screening for colorectal cancer was found to be very low (3.5\%) in 567 patients with colorectal cancer [15]. In our study, only one in five of 50-year and older participants of the Faculty of Medicine were screened for colorectal cancer via a fecal occult blood test in the last year. This rate was even lower for participants of the Faculty of Agriculture. The colonoscopy rate in the last ten years was $16.5 \%$ in our sample. In Turkey, 50 -year and older individuals can be easily screened for colorectal cancer with a fecal oc- cult blood test in family practice clinics. Our rate is higher than the national rate; however, it is quite low compared to that of the USA (59-65\%) [16, 17].

More than half of the participants $(59.5 \%)$ were in favor of screening tests in our study. Although the recommendations for screening tests in periodic health examinations are frequently updated, the low rates of screening tests in our study indicates that we, as family physicians, need to do more to increase the level of knowledge and awareness and action for PHE. Understanding beliefs about health has an important role in achieving success in preventive health care services [18].

It has been shown that a self-assessed health status as 'bad' is significantly related to increased mortality, chronic diseases and outpatient admissions $[19,20]$. In our study, $67.8 \%$ of the participants evaluated their overall health status as 'good', $18 \%$ as 'moderate' and $14.1 \%$ as 'very good'. The national data in 2012 showed similar rates [10]. The participants who evaluated their health status as 'moderate' in the Faculty of Agriculture were significantly more willing to undergo screening tests. There may be a desire to undergo screening tests due to health concerns. The opposite situation may also be true; undergoing screening tests regularly can reduce health concerns and increase confidence in health.

The participants who exercise regularly in our study assessed themselves to be healthier. Several studies emphasized the significant relationship between a self-assessed health status and healthy behaviors (no smoking, no consumption of alcoholic drinks, healthy diet) [21-24].

A study concerning a change in health behavior showed that lifestyle behaviors such as smoking, alcohol consumption, exercise and diet have improved in people who had periodic health examinations [25].

Number of visits for having a periodical health examination is affected by many factors, including age, gender, educational and socio-economic status and knowledge and perception about PHE.

In Turkey, the mean number of admissions to a family physician per year is 2.9 [26]. Family physicians are key health care providers for counseling and early diagnosis of diseases. Family physicians who are responsible for PHE should update the knowledge of PHE and perform a PHE for every individual. We, as family physicians, need to do more to increase the level of knowledge and awareness and visits ratio for PHE. Understanding beliefs about health has an important role in achieving success in preventive health care services [26].

Primary health care plays an important role in the implementation of public health operations, including health protection, health promotion and disease prevention [27].

\section{Limitations of the study}

Our study, as far as we know, is the first study in our country about periodic health examination attitudes of academicians. Our questionnaire consisted of several topics including cancer screening, blood pressure and blood lipid level measurements, vaccinations, healthy life style (smoking behavior, alcohol consumption, regular physical activity), and depression screening.

However, our study has some limitations. First, our sampling procedure included only 392 out of 1900 (20.6\%) academicians in Cukurova University. Therefore, our findings cannot be generalized. Further studies are required to have more accurate data on periodic health examination attitudes of academicians. Second, we used a self-developed questionnaire to learn periodic health examination behaviors of academicians. Thus, the data collection tool has no international validity and reliability. Third, 205 out of 392 valid questionnaires might have been completed by the individuals who had previous awareness and interest in this topic and this might have caused a bias. Fourth, we collected data in five months. More participants could have 
been reached if the study time could have been longer. Fifth, the academicians were selected in two different faculties (Medicine and Agriculture) however; we could not compare them to conclude whether there was a significant difference between the participants of two faculties.

Nevertheless, we believe that our study has some contribution as having this essential task of family physicians as a topic and giving some idea about our country's university academicians' health behaviors.

\section{Conclusions}

Knowledge and behavior for periodic health examinations seem to be significantly related to age, gender and socio-economic status, perception about periodic health examinations, health concerns and current state of health. The low rates of periodic health examinations even in a very highly educated sample of individual suggests that family physicians have more to do to increase the awareness levels of individuals and society about the benefits and importance of periodic health examinations.

Source of funding: This work was funded by the authors' own resources.

Conflict of interest: The authors declare no conflict of interests.

\section{References}

1. McWhinney IR. A textbook of family practice. $2^{\text {nd }}$ ed. New York-Oxford: Oxford University Press; 1997: 3-28, 37-103, $179-227$.

2. Republic of Turkey Ministry of Health. Course notes for family doctors. 2004: 99-100 (in Turkish).

3. Virgini V, Meindl-Fridez C, Battegay E, at al. Check-up examination: recommendations in adults. Swiss Med Wkly 2015; 145: w14075, doi: 10.4414/smw.2015.14075.

4. Tengs TO, Adams ME, Pliskin JS, et al. Five-hundred life-saving interventions and their cost-effectiveness. Risk Anal 1995; 15(3): 369-390.

5. Republic of Turkey Ministry of Health. Directorate of Primary Health Care Services. Global Adult Tobacco Survey Turkey Report 2010. Ministry of Health Publication no: 803 (in Turkish).

6. Turkish Institude of Statistics. Global Adult Tobacco Survey 2012 [cited 8.01.2016]. Available from URL: http://www.tuik.gov.tr (in Turkish).

7. Republic of Turkey Ministry of Health. Directorate of Public Health. Turkey Burden of Disease Study 2004 [cited 8.01.2016]. Available from URL: http://ekutuphane. tusak. gov. tr/kitaplar/turkiye_hastalik_yuku_calismasi.pdf (in Turkish).

8. Republic of Turkey Ministry of Health. Directorate of Primary Health Care Services. Turkey Obesity Control Program [cited 8.01.2016]. Available from URL: http://karasudh.saglik.gov.tr/userfiles/file/turkiye_obezite_sismanlik_ile_mucadele_ve_kontrolprogrami_2010_2014.pdf (in Turkish).

9. World Health Organization. Global status report on alcohol and health 2014 [cited 8.01.2016]. Available from URL: http://apps.who. int/iris/bitstream/10665/112736/1/9789240692763_eng. pdf.

10. Turkish Institude of Statistics. Health Survey 2012 [cited 8.01.2016]. Available from URL: http://www.tuik.gov.tr/Start.do (in Turkish).

11. Turkish Institude of Statistics. Turkey Health Survey 2014 [cited 8.01.2016]. Available from URL: http://www.tuik.gov.tr/PreHaberBultenleri. do?id=18854 (in Turkish).

12. Turkish Institude of Statistics. Statistics for Causes of Death 2015 [cited 8.01.2016]. Available from URL: http://www.tuik.gov.tr/PreHaberBultenleri. do?id=21526 (in Turkish).

13. Republic of Turkey Ministry of Health. Periodic Health Examinations and Screening Tests Guideline for Family Practice in Turkey 2015. Publication no: 991 (in Turkish).

14. Zemheri E, Koyuncuer A. Pap Smear Test in early diagnosis of cervical cancers. STED 2005; 14: 1-4 (in Turkish).

15. Aydınlı MS, Kuzu A, Tekiner S. Preventive care and diagnosis of patients with colorectal cancer. Ankara University Faculty of Medicine 2011 [cited 12.01.2016]. Available from URL: http://acikarsiv.ankara.edu.tr/browse/29246/tez. pdf (in Turkish).

16. Hudson SV, Ferrante JM, Strickland PO, at al. Physician recommendation and patient adherence for Colorectal Cancer Screening. J Am Board Fam Med 2012; 25(6): 782-791.

17. CDC Database. Vital signs: Colorectal Cancer Screening Test use in United States 2012. MMWR Morb Mortal Wkly Rep 2013; 62(44): 881-888.

18. Cherrington A, Corbie-Smith G, Pathman DE. Do adults who believe in periodic health examinations receive more clinical preventive services? Am J Prev Med 2007; 45(4): 282-289.

19. Mossey JM, Shapiro E. Self-rated health: a predictor of mortality among the elderly. Am J Public Health 1982; 72(8): 800-808.

20. Idler EL, Angel RJ. Self-rated health and mortality in the NHANES-I Epidemiologic Follow-up Study. Am J Public Health 1990; 80(4): 446-452.

21. Sung NJ, Markuns JF, Park KH, at al. Higher quality primary care is associated with good self-rated health status. Fam Pract 2013; 30(5): 568-575.

22. Kepka D, Ayala GX, Cherrington A. Do Latino immigrants link self-rated health with BMI and health behaviors? Am J Health Behav 2007; 31(5): 535-544.

23. Baruth M, Becofsky K, Wilcox S, at al. Health characteristics and health behaviors of African American adults according to self-rated health status. Ethn Dis 2014; 24(1): 97-103.

24. Cathleen M, Shultz S. Lifestyle assesment. Nurs Clin North Am 1984; 19(2): 271-281.

25. Son $\mathrm{KY}$, Lee $\mathrm{CM}, \mathrm{Cho} B$, at al. Effect of additional brief counselling after periodic health examination on motivation for health behaviour change. J Korean Med Sci 2012; 27(11): 1285-1291.

26. Republic of Turkey Ministry of Health. Directorate of Public Health. Health Statistics 2013 [cited 16.07.2016]. Available from URL: http://ekutuphane.sagem.gov. tr/kitaplar/saglik_istatistikleri_yilligi_2013.pdf (in Turkish).

27. Tyszko P, Nitsch-Osuch A, Minko M, et al. Primary health care tasks in implementing the main operations of public health. Fam Med Prim Care Rev 2016; 18(3): 394-397.

Tables: 5

Figures: 0

References: 27

Received: 12.01 .2017

Revised: 15.03.2017

Accepted: 28.03.2017
Address for correspondence:

Emrah Ersoy, MD

Cukurova University School of Medicine

Department of Family Medicine

Balcali 01330 Saricam, Adana, Turkey

Tel.: +90-553-48568 05, fax: +90-322-338 6023

E-mail: dremrahersoy86@gmail.com 